\title{
Pedagogical Support of Socio-Professional Self-Determination of Students
}

\author{
Hanna Podliesna ${ }^{1, *}$, Dmytro Bazela ${ }^{2}$, Olha Bilash $^{2}$, Liudmyla Vyshotravka ${ }^{2}$, Liudmyla Khotsianovska ${ }^{2}$ \& Hanna \\ Perova $^{2}$ \\ ${ }^{1}$ Department of Humanities and Social Sciences, Poltava State Agrarian University, Poltava, Ukraine \\ ${ }^{2}$ Department of Choreographic Art, Kyiv National University of Culture and Arts, Kyiv, Ukraine \\ *Correspondence: Poltava State Agrarian University, 1/3, Skovoroda Str., Poltava, 36003, Ukraine
}

Received: December 7, 2021

Accepted: January 6, 2022 Online Published: January 17, 2022

doi:10.5430/jct.v11n1p154

URL: https://doi.org/10.5430/jct.v11n1p154

\begin{abstract}
Recently, the prevailing trend is that graduates do not work in their profession; the purpose of the article is to study ways to improve the effectiveness of social and professional self-determination of students. The authors conducted an empirical study of the causes of this phenomenon and identified the main ones (the choice was made for the student by his parents; in the process of studying, the student became disillusioned with the chosen profession; the chosen profession does not bring the necessary earnings; did not find a job in the speciality). The article noted that the percentage of work in the profession depends on how long ago the specialist graduated from the university. The authors identified what causes could be eliminated in the process of teaching students. Having analyzed the existing pedagogical methods for students' more confident social and professional self-determination, the authors proposed the conceptual foundations of pedagogical support for students' social and professional self-determination. These recommendations will make it possible to correct students' social and professional self-determination in their speciality. The authors proposed an algorithm that allows to visually and transparently determine the student's attitude to the chosen speciality and ways to persuade the student to look for a job and work in the profession and the necessary tools for this. The proposed dual approach to adjusting the socio-professional self-determination of students will allow them to identify the problem at an early stage, track it and fix it with adjustment. Research has shown that there are several main reasons why a student does not work in a profession. All these reasons, in our opinion, are subject to correction in the learning process. The main feature of success is the desire of the university to identify such students at an early stage, a developed adjustment mechanism and constant control and monitoring. A further promising direction of research is the development of questionnaires that can identify this problem and a mechanism for attracting artificial intelligence that can guide each student individually and signal when the university's intervention is necessary.
\end{abstract}

Keywords: pedagogical support, self-determination, professional self-determination, professional identity

\section{Introduction}

The most important directions in the development of modern education are the intellectualization of the content of the educational process, the introduction of new forms of education, the creation of conditions for students, the formation of a safe environment, the development of their creative abilities. Ultimately, all this should affect the training of specialists who, in a market economy, intensified competition in the labour market, will be able to solve the problem of employment. The amorphousness of target attitudes, the abstractness of value orientations, the ideological vacuum in the conditions of the transformation of society, the destabilization of the economy, permanent crisis phenomena and the decline in living standards lead to deformations of the consciousness of young people (Trach et al., 2020; Gumenyuk et al., 2021). Uncertainty about the future, lack of initiative and anxiety characterize young people, especially immediately after graduation from the university. There are several criteria for assessing the effectiveness of the functioning of the higher education system, one of which is the success of the employment of university graduates (Gamage \& Henegedara, 2019; Pelinescu \& Simionescu, 2019; Bodnar \& Rybalochka, 2021; Isakovic et al., 2021). Recently, the prevailing trend has been that graduates do not work in their profession (The Guardian, 2018; Redden, 2020; Fox, 2021). Further intensification of this phenomenon should be expected in the 
coming years. To develop recommendations for correcting this phenomenon, you must first identify it. Thus, the purpose of the article is to study ways to improve the effectiveness of social and professional self-determination of students. This goal assumes the fulfilment of the following tasks:

- analysis of the theoretical basis;

- conducting research to identify the reasons why graduates do not work in their speciality;

- the introduction of pedagogical support to improve students' social and professional self-determination.

\section{Literature review}

Studying the problem of professional self-determination of university students has always been a topical psychological and pedagogical direction for scientists from all countries. It aims to activate students to a conscious process of professional self-determination at the university, which allows them to provide the most appropriate training for them.

The analysis of the psychological and pedagogical literature has revealed several authors studying the problem of professional self-determination. In the studies of these authors, professional self-determination is considered from different angles:

- as a series of tasks that society poses to an individual (Absatova et al., 2021; Xu et al., 2021);

- as a process of gradual decision-making, through which a person forms a balance between his preferences and the needs of the system of division of labour in society (Bodnar \& Rybalochka, 2021; Casino-García et al., 2021; Chiu et al., 2021; Poplavskyi, 2019);

- as a process of forming an individual lifestyle, of which professional activity is a part (Galiakhmetova, 2019; Yalovenko, 2021; Revyakina \& Manuylova, 2021; Shytyk \& Akimova, 2020; Vasiutiak et al., 2021).

In recent years, many studies have been carried out on the problems of professional training of students (Gumennykova et al., 2020; Bashynska et al., 2021; Prokopenko et al., 2020). The choice of the subject of future activity is a manifestation of the individual's mental activity as a result of the interiorization of external factors through the motivational-need-sphere of the individual. The choice should not be imposed; otherwise, the object will cease to be motivating, and the activity will cease to be an activity. The choice of the subject of future activity can be based only on a real decision of the individual, taken voluntarily. Despite the fact that society provides maximum independence in choosing the type of labour activity, freedom of professional choice has several significant restrictions dictated by subjective and objective circumstances. The first, subjective, largely depends on a person's internal position, knowledge, skills, abilities, desire for self-knowledge, and self-improvement. The second, objective, is dictated by the living conditions and the profession's requirements on the individual. Accordingly, the absence of an adequate "I-concept", ideological choice, educational and professional motivation, unstable self-esteem, confusion of values, a distorted manifestation of internal factors, or an imbalance in external life circumstances - any disturbing aspect complicates the process of professional self-determination.

Table 1. Criteria and Indicators of Social and Professional Self-Determination

\begin{tabular}{cl}
\hline Criterion & Index \\
\hline \multirow{2}{*}{$\begin{array}{c}\text { Readiness for professional } \\
\text { self-identification }\end{array}$} & - awareness and presentation of the directions of professional activity; \\
& - certainty in understanding with whom and where to work; \\
& - an idea of the prospects in their work activities. \\
& - the formation of knowledge about a career and types of career development, job search \\
& strategies, the content of career orientations, professional positions and roles, the \\
& requirements of professional positions to personal characteristics; \\
& - motivation to achieve success in educational and professional activities; \\
Willingness to design a & - striving for self-disclosure and self-realization in professional activity; \\
professional career & - analysis of one's capabilities and characteristics and their correlation with the \\
& requirements of certain professional positions, the ability to critically assess personal \\
& qualities, the development of abilities and skills of self-regulation. \\
\hline
\end{tabular}


In our study, socio-professional self-determination is an open, dynamic process. The student's goals in the field of professional development are correlated with career preferences, as well as the readiness for professional self-identification and for the design of a professional career formed. Based on this definition, we theoretically identified two social and professional self-determination criteria - the readiness for professional self-identification and the readiness to design a professional career, and the indicators were determined (Table 1).

Accordingly, for a full-fledged choice of a person, an adequate idea of each of the professional alternatives is necessary, that is, the process of forming the image of each profession, building a vision of a possible future that arises as a result of choosing one or another alternative is essential. Since the consequences of professional self-determination affect almost all aspects of life, we can talk about different options for the personal future of a young person as a whole. Note that the image of a future profession is a rather complex education that includes emotional and cognitive components. The correspondence of the emotional-evaluative components to the essential content components of the profession makes a choice reasonable and realistic. In other words, with the requirements of the profession reflecting the concept of "must", individual components must intersect, namely: the motivational concept "I want" and the individual psychological concept of "I can".

When entering a university, it is assumed that the applicant must know what kind of profession he chooses, what his future activities will consist of, whether he will be able, based on his capabilities, desires and needs, to work in this field after graduation (i.e. e. have specific skills of professional readiness: planning, self-control, etc.). The complex of pedagogical conditions that ensure the effective functioning of the professional education system of a specialist in the process of teaching disciplines includes:

- creation of situations of choice at each stage of professional education;

- differentiation of goals, objectives and content of professional education, taking into account the individual characteristics of students;

- focus of the educational process on solving the problems of professional education, on building a system of professional relations;

- building the process of professional education based on the leading role in it of the program of self-realization and self-development of the personality of the future specialist;

- organization of cooperation based on mutual trust, dialogue, the establishment of subject-subject relations between the teacher and students;

- orientation of students in the values of future professional activity;

- construction of the content of courses of disciplines, taking into account the orientation towards self-knowledge, self-development, introspection, resolution of internal conflicts, construction of positive life and professional plans (Jarvis, 1983; Prokhorova \& Vaganova, 2019; Fawns et al., 2021; Koff, 2021; Zhuravlova et al., 2021).

The constitutive basis of this type of upbringing is the profession. Professional education aims to ensure the social and professional development of the individual, update the individual's psychological potential, and meet the need for social and professional self-determination. For the implementation of personality-oriented professional education, it is required to provide the necessary pedagogical conditions:

- professional competence of teachers;

realization of the rights of students to quality education;

- the content of education, adequate to socio-cultural realities and trends in the development of civilization;

- variability and differentiation of education, allowing to adapt the pedagogical system to students with different individual psychological characteristics;

- unity of actions of all subjects of the educational process (students, parents, teachers, administration);

- a complex of developing, personality-oriented pedagogical technologies;

- protection and strengthening of students' health (valeology of the educational process and environment) (Meyer, 2020; Semigina et al., 2020; Vaganova et al., 2020; Bondar et al., 2021; Humeniuk et al., 2021; Hough, 2021).

The process of personality self-determination is influenced by a wide variety of factors, including conflicts (confrontation of the educational environment, interpersonal relations, "colour revolutions", socio-political conflicts, protest manipulation technologies, conflicts in choosing a profession, etc.), the reasons for which are inconsistencies between the subjective (mental) life of a particular person and the real, objective reality of the world around him and 
which can be designated as "conflicting realities of life."

The most crucial criterion for a person's professional development is professional identity. Personal meanings, motives, values, and ideological attitudes are integrated, which is closely interconnected with the image of "I am a professional". At the same time, identity is a "fusion" of understanding the goal, methods of activity, knowing oneself, one's abilities, one's plans - life and professional, the formation of which occurs in the process of professional self-determination, during which not only the content and meaning of the future profession are mastered, but also orientation is carried out in a socio-cultural situation, in its demands for professionalism, when there is a "trying on" the requirements of the profession, the identification of opportunities in it for self-actualization and self-development, for the realization of their life values and plans. The professional identity reflects, first of all, the subjective acceptance of the value of the chosen profession, but at the same time, the semantic frame is set not only by the space of individual attitudes but also by the whole set of socio-cultural conditions taken concerning the individual's need for self-realization in real activity. Professional identity develops as a result of professional educational activity, being its result and at the same time a condition for the successful mastery of knowledge, skills and abilities for further professional activity. An effective mechanism for making sense of meaning, which can be assimilated into pedagogical science and practice to create favourable conditions for the professional self-determination of students, is the development of the ability to consider one's professionalism as a concept, a "project" that requires implementation.

Interpersonal relationships that develop in the process of professional self-determination significantly impact the socialization and professionalization of a person: only in joint activities and communication is the development of personality possible. The nature of interpersonal interaction, acceptance or non-acceptance of a person by a reference group (educational or professional), subjective perception and reflection of social relations are conflictions, generating conflicting realities of professional self-determination of the individual.

\section{Methods}

The authors conducted an empirical study to determine the main reasons graduates do not work in their speciality. To do this, the authors surveyed university graduates to find out whether they work by profession. A total of 392 people took part in the survey. The survey was mainly conducted in Google Docs (90\%), 10\% of respondents answered in person (graduates of Poltava State Agrarian University and Kyiv National University of Culture and Arts). The respondents were divided into 3 groups: group 1 - graduated from the university from 0 to 3 years ago, group 2 - graduated from the university 4-9 years ago, 1 group - graduated from the university more than 10 years ago.

After identifying the reasons, the authors, based on the literature analysis, develop ways to improve the social and professional self-determination of students. The authors used the following basic methods: structural and logical analysis, scientific abstraction, systematization, generalization, concretization and comparative analysis.

\section{Results}

The processing of the results showed that the results differ from how long ago the specialist graduated from the university; therefore, the respondents' answers (Figure 1).

Thus, summarizing for the entire population of respondents, the main reasons why graduates do not work in their speciality are:

1) the chosen profession does not bring the necessary earnings $(25,67 \%)$;

2) the choice was made for the student by his parents $(22,93 \%)$;

3 in the process of studying, the student became disillusioned with the chosen profession $(21,9 \%)$;

4) did not find a job in the speciality $(21,23 \%)$.

5) It is worth noting that, among other reasons, there was such as "my profession does not benefit society" (almost $5 \%$, more typical for groups 2 and 3 ).

We are convinced that all the reasons can be corrected in the learning process, in one way or another, if you use the right tools. 


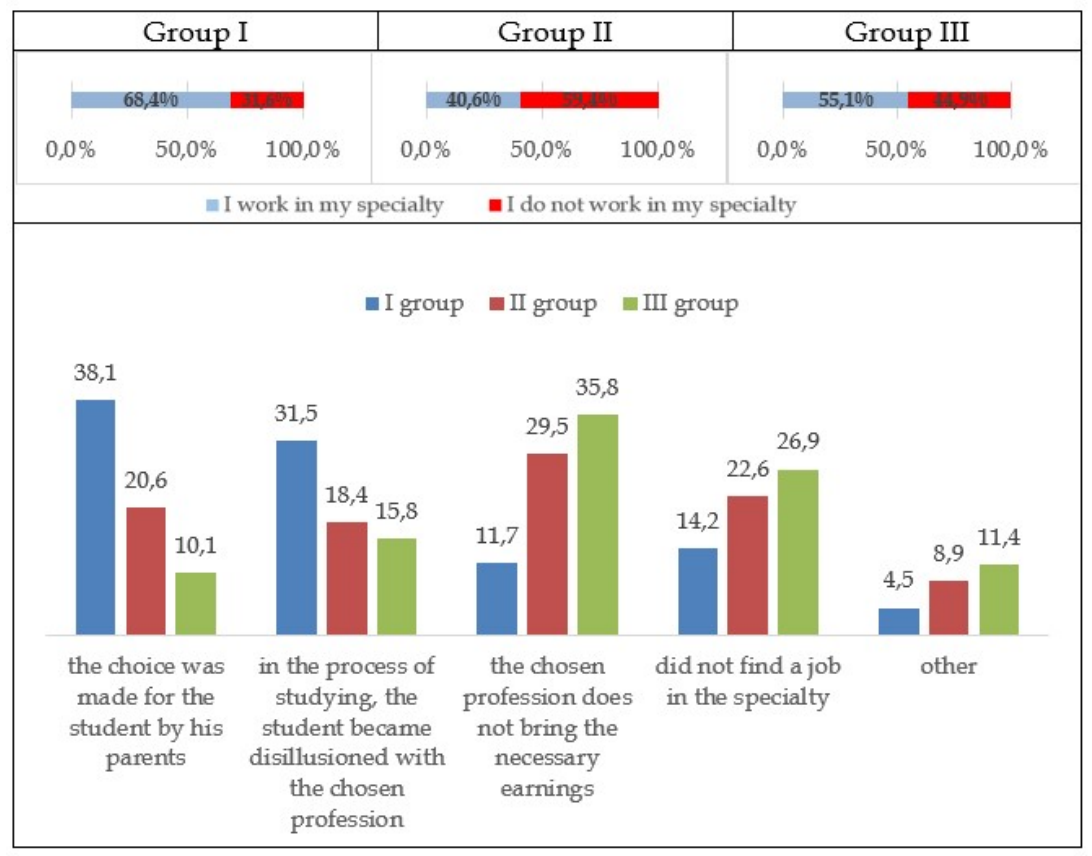

Figure 1. Results of a Survey of Students Regarding the Reasons for not Working in Their Speciality Source: compiled by the authors

\section{Discussion}
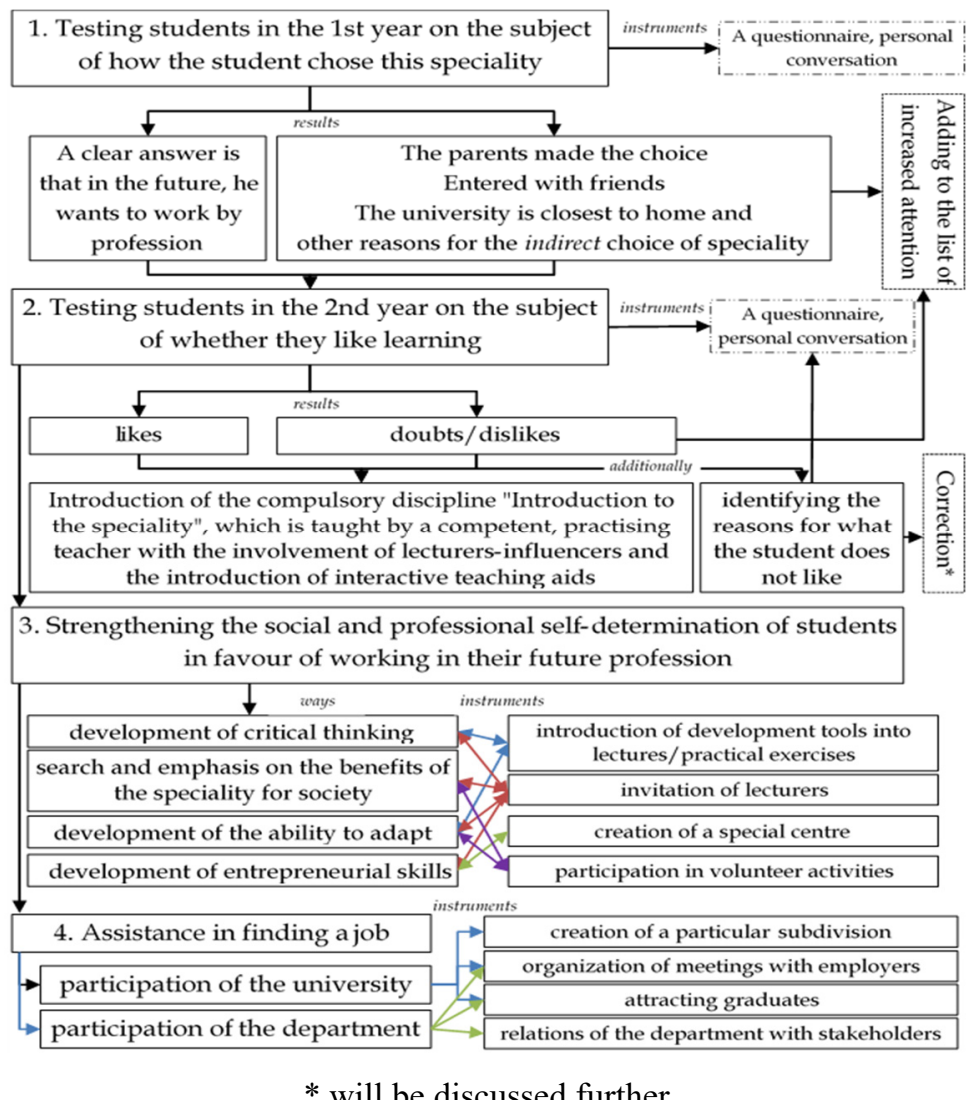

Figure 2. Algorithm for Pedagogical Support of Social and Professional Self-Determination of Students Source: developed by the authors 
Theoretical and empirical research has shown that the problem of social and professional self-determination of students exists. Still, some tools can correct it in the process of teaching students.

We offer an algorithm for pedagogical support of social and professional self-determination of students (Figure 2).

Thus, we will determine at what stages the identified problems are solved (Table 2). In addition to the main 4 problems, we added the 5th one; it did not occupy a large percentage of the respondents' answers; however, we believe that it is significant for society as a whole that this problem will only progress, so we need to do so to act proactively.

Table 2. Detailing the Solution to Previously Identified Problems

\begin{tabular}{lc}
\hline \multicolumn{1}{c}{ Problem } & Levelling stage \\
\hline the chosen profession does not bring the necessary earnings & 3,4 \\
the choice was made for the student by his parents & 1,3 \\
in the process of studying, the student became disillusioned with the chosen profession & 2,3 \\
did not find a job in the speciality & 3,4 \\
my profession does not benefit society & 3 \\
\hline
\end{tabular}

Source: developed by the authors

Thus, we see that the main problems are solved by an integrated dual approach, i.e. early identification and subsequent adjustment. The proposed algorithm (Figure 2) contains the block "Correction*". Let's dwell on it in more detail. If the majority of students do not like the way the disciplines are taught, this is one of the most severe issues and requires increased attention because teaching is the main task of the university.

First, it is necessary to determine whether these are isolated or more widespread cases. If it is an isolated case, it is required to develop an individual learning trajectory for the student - either in several subjects or throughout the entire training.

Thirdly, when identifying the mass character, it is necessary to conduct additional analysis to identify whether this is the result of individual teachers' actions or the teaching system at the department as a whole. It is also necessary to conduct a conversation with individual teachers and test for professional competence. If deviations are detected, propose an adjustment; if an adjustment is impossible, dismiss the teacher.

If it concerns the teaching system at the department as a whole, then, with the consent of the students, conduct a "brainstorm" with the presence of teachers, guarantor, head of the department, dean and a representative of the administration to search for possible ways. If students are afraid of the consequences, it is necessary to involve an independent third party; it can be representatives of student government, or representatives of the scientific community of the university, or senior students, or a group of the listed possible participants. More clearly, we will present the correction block in Figure 3.

It is worth noting that the success of any improvement/adjustment depends on constant monitoring of the situation. Likewise, the work with students' dissatisfaction should not be completed after correction; it requires continuous monitoring, and the process is cyclical until the complete graduation of students. 


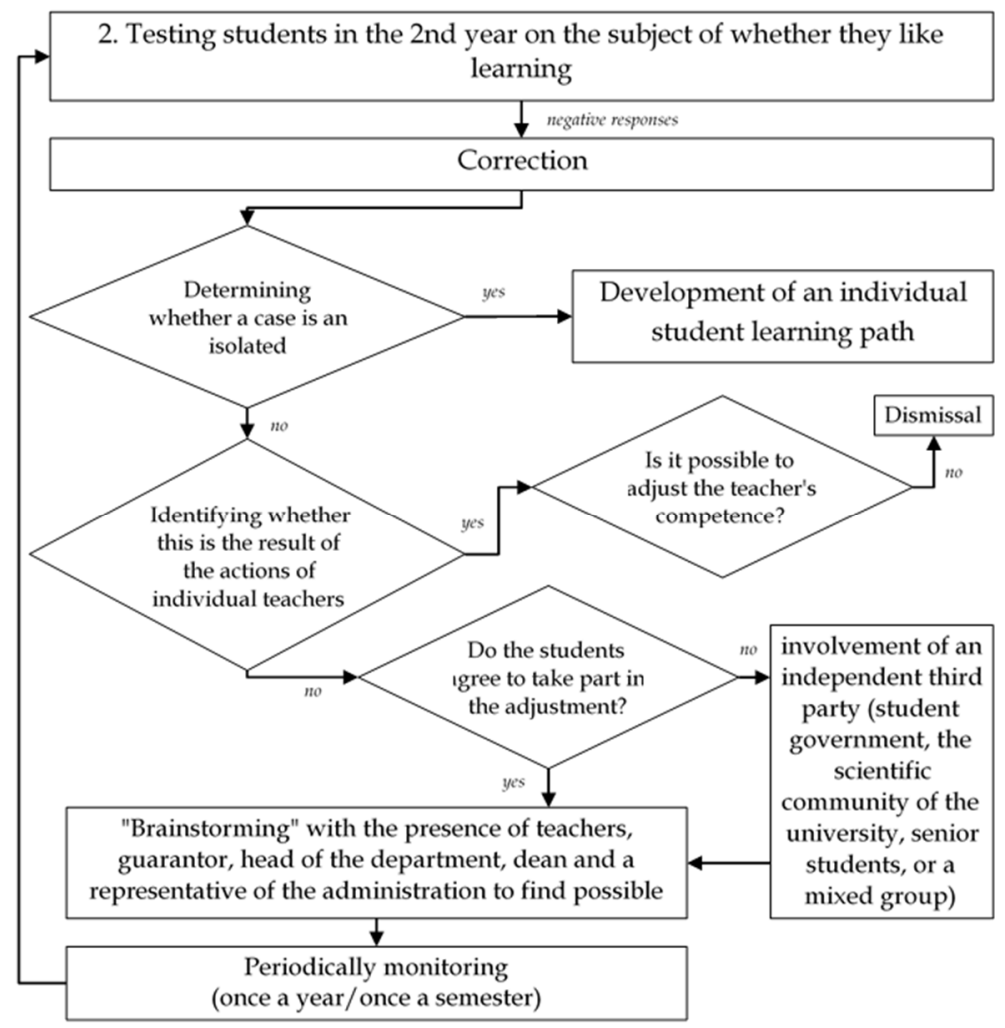

Figure 3. Tools for Correcting Student Dissatisfaction with the Teaching System

Source: developed by the authors

\section{Conclusions}

The study confirmed the hypothesis that the majority of students in the future would work outside their speciality. This causes great harm to the education system; such graduates understand that they have wasted 3-5 years of their lives on education. At the same time, not everyone understands that in the process of training, they developed not only Hard skills (which were not helpful to everyone), but also Soft skills (which were helpful in absolutely all graduates, both in another job and in everyday life). Secondly, if students were educated at the expense of government funding, then this is a waste of government resources. Thirdly, it is challenging to predict employment in a particular profession and plan budgetary funding given this state of affairs.

Research has shown that there are several main reasons why a student does not work in a profession. All these reasons, in our opinion, are subject to correction in the learning process. The main feature of success is the desire of the university to identify such students at an early stage, a developed adjustment mechanism and constant control and monitoring.

A further promising direction of research is the development of questionnaires that can identify this problem and a mechanism for attracting artificial intelligence that can guide each student individually and signal when the university's intervention is necessary.

\section{References}

Absatova, M., Dzhanbubekova, M., Baubek, S., Gulnara, Y., \& Gaulmir, S. (2021). Study of the level of professional self-determination of students in grade 9. Review of International Geographical Education Online, 11(5), 429-438. https://doi.org/10.48047/rigeo.11.05.44

Bashynska, I., Garachkovska, O., Kichuk, Ya., Podashevska, T., \& Bigus, O. (2021). Smart Education 4.0: Balancing Dual-Distance and Reskilling Revolution. Studies of Applied Economics, 39(6), 1-11. https://doi.org/10.25115/eea.v39i6.5262

Bodnar, A., \& Rybalochka, K. (2021). Peculiarities of Professional Self-Determination of Students. Psychology and 
Psychosocial Interventions, 3, 3-10. https://doi.org/10.18523/2617-2348.2020.3.3-10

Bondar, I., Gumenyuk, T., Horban, Y., Karakoz, O., \& Chaikovska, O. (2021). Distance E-learning in the system of professional development of corporation managers: Challenges of COVID-19. Journal of Education and e-Learning Research, 7(4), 456-463. https://doi.org/10.20448/journal.509.2020.74.456.463

Casino-García, A. M., Llopis-Bueno, M. J., \& Llinares-Insa, L. I. (2021). Emotional intelligence profiles and self-esteem/self-concept: An analysis of relationships in gifted students. International Journal of Environmental Research and Public Health, 18(3), 1-23. https://doi.org/10.1016/10.3390/ijerph18031006

Chiu, T., Chai, C. S., Williams, P. J., \& Lin, T. J. (2021). Teacher Professional Development on Self-Determination Theory-Based Design Thinking in STEM Education. Educational Technology and Society, 24(4), 153-165.

Fawns, T., Mulherin, T., Hounsell, D., \& Aitken, G. (2021). Seamful learning and professional education. Studies in Continuing Education, 43(7), 1-17. https://doi.org/10.1080/0158037X.2021.1920383

Fox, M. (2021). Out of work and desperate: Here's what college graduates are facing and what they can do about it. Retrieved from https://www.cnbc.com/2021/04/15/what-college-graduates-can-do-about-being-out-of-work.html

Galiakhmetova, N. (2019). Age Features of Professional Self-Determination of Personality. Bulletin of Kalashnikov ISTU, 21(4), 279. https://doi.org/10.22213/2413-1172-2018-4-279-282

Gamage, M., \& Henegedara, P. (2019). Employability of university graduates; Investigation of graduate's and employer's perspectives on employability. International Journal of Scientific and Research Publications, 9(7), 946-955. https://doi.org/10.29322/IJSRP.9.07.2019.p91124

Gumennykova, T., Pankovets, V., Liapa, M., Miziuk, V., Gramatyk, N., \& Drahiieva, L. (2020). Applying instructional design methods to improve the effectiveness of blended-learning. International Journal of Management, 11(5), 31-42. https://doi.org/0.34218/IJM.11.5.2020.004

Gumenyuk, T., Frotveit, M., Bondar, I., Horban, Y., \& Karakoz, O. (2021). Cultural diplomacy in modern international relations: The influence of digitalization. Journal of Theoretical and Applied Information Technology, 99(7), 1549-1560.

Hough, S. (2021). Professional Educational Opportunities. Sexuality and Disability, 39(2), 1-3. https://doi.org/10.1007/s11195-021-09695-y

Humeniuk, T., Bondar, I., Batchenko, L., Horban, Y., \& Honchar, L. (2021). State Regulation of the Development of Educational and Scientific Process in Higer Education Institutions. Journal of Management Information and Decision Science, 24(2), 1-10.

Isakovic, S., Brkic, A., \& Kulovic, D. (2021). The role and the importance of competencies for the employability of University graduates. BH Ekonomski forum, 13(2), 167-185. https://doi.org/10.5937/bhekofor2102167I

Jarvis, P. (1983). Professional Education. London: Routledge. https://doi.org/10.4324/9781351003223

Koff, S. (2021). The First Stage of Professionalization: Education. In Koff, S. (Ed.), The Dental Team in the European Union (pp.21-59). Cham: Springer Nature Switzerland. https://doi.org/10.1007/978-3-030-72232-6_2

Meyer, R. (2020). Competence and Continuing Professional Education. In Meyer, R. (Ed.), The New Yellow Book: Government Auditing Standards (pp. 74-89). Hoboken, NJ: Wiley. https://doi.org/10.1002/9781119784722.ch4

Pelinescu, E., \& Simionescu, M. (2019). Higher Education Policies and Employability of University Graduates in the EU-28. Journal of Intercultural Management, 11(3), 105-133. https://doi.org/10.2478/joim-2019-0020

Poplavskyi, M. (2019). Entrepreneurship in the field of art business in the European union. Journal of Entrepreneurship Education, 22(6).

Prokhorova, M., \& Vaganova, O. (2019). Design and implementation of an educational event in the training of future managers. Vestnik of Minin University, 7(1), 4. https://doi.org/10.26795/2307-1281-2019-7-1-4

Prokopenko, O., Osadchenko, I., Braslavska, O., Malyshevska, I., Pichkur, M., \& Tyshchenko, V. (2020). Competence approach in future specialist skills development. International Journal of Management, 11(4), 645-656. https://doi.org/10.34218/IJM.11.4.2020.062

Redden, E. (2020). 41\% of Recent Grads Work in Jobs Not Requiring a Degree. Retrieved from https://www.insidehighered.com/quicktakes/2020/02/18/41-recent-grads-work-jobs-not-requiring-degree 
Revyakina, N., \& Manuylova, N. (2021). Students' personal self-determination as an integral part of the educational process. E3S Web of Conferences, 273. https://doi.org/10.1051/e3sconf/202127312148

Semigina, T., Vysotska, Z., Kyianytsia, I., Kotlova, L., Shostak, I., \& Kichuk, A. (2020). Psycho-emotional state of students: Research and regulation. The Recent Economic Trends and their Impact on Marketing, 38(4). https://doi.org/10.25115/eea.v38i4.4049

Shytyk, L., \& Akimova, A. (2020). Ways of transferring the internal speech of characters: Psycholinguistic projection. Psycholinguistics, 27(2), 361-384. https://doi.org/10.31470/2309-1797-2020-27-2-361-384

The Guardian. (2018). Too many graduates are mismatched to their jobs. What's going wrong? Retrieved from https://www.theguardian.com/higher-education-network/2018/jan/25/too-many-graduates-are-mismatched-to-th eir-jobs-whats-going-wrong

Trach, Y., Tolmach, M., Chaikovska, O., \& Gumeniuk, T. (2020) Problems of Cultural Heritage Preservation in the Context of the Armed Conflict Growth. 4th International Conference on Information Technology in Disaster Risk Reduction (ITDRR), 31-44. https://doi.org/10.1007/978-3-030-48939-7_4

Vaganova, O., Gladkov, A., Korostelev, A., \& Maksimova, K. (2020). Personal-oriented professional education. Baltic Humanities Journal, 9(2), 112-115. https://doi.org/10.26140/bgz3-2020-0902-0029

Vasiutiak, I., Babych, O., Shoptenko-Ivanova, O., Zhuravlova, A., Myroniuk, N., \& Nebesnyk, A. (2021). The Role of Sports Dance in Ensuring the Motor Activity of Students. International Journal of Human Movement and Sports Sciences, 9(6), 1299-1305. https://doi.org/10.13189/saj.2021.090625.

Xu, Y., Liu, S., Li, R., Guan, Y., \& Zhou, W. (2021). Self-consistency and self-determination perspectives of career value changes: A cross-lagged panel study among Chinese university students. Journal of Vocational Behavior, 127, 103584. https://doi.org/10.1016/j.jvb.2021.103584

Yalovenko, O. (2021). Methods and technologies for professional self-determination of students in the USA. Problems of Modern Teacher Training, 1(23), 59-65. https://doi.org/10.31499/2307-4914.1(23).2021.232764

Zhuravlova, Y., Kichuk, N., Zhuravska, N., Yakovenko O., Zhytnyk, V., \& Yashchuk, S. (2021). The problem field of professional (vocational) education: Innovations and ways to improve. Applied Economics Studies, 39(5). https://doi.org/10.25115/eea.v39i5.5274

\section{Copyrights}

Copyright for this article is retained by the author(s), with first publication rights granted to the journal.

This is an open-access article distributed under the terms and conditions of the Creative Commons Attribution license (http://creativecommons.org/licenses/by/4.0/). 